\title{
RETHINKING BuRAWOY: REFLECTIONS From CanAdian Feminist Sociology
}

\author{
Gillian CREeSE \\ Arlene Tigar McLaren \\ Jane PUlKingham
}

\begin{abstract}
In this paper, we take up the debate about public sociologies by drawing on critical feminist sociology in Canada. While we applaud Burawoy's efforts to contextualize US sociology and to embrace engagement with various publics, we discuss four limitations of his model. First, it does not adequately reflect the practice of feminist research that is interdisciplinary and simultaneously professional, critical, policy, and public sociology. Second, it does not take into account feminist methodology as an integrative form of sociology. Third, it does not sufficiently provincialize US sociology nor address how American "professional" sociology can operate as a threat rather than a standard-bearer in Canada. Fourth, it requires more concrete examples of public sociology and how it is undertaken in specific situations. We briefly discuss our research to illustrate "organic" public sociology in the Canadian context.
\end{abstract}

Key words: critical feminist sociology, feminist methodology, Canadian sociology, organic public sociology

Résumé. Dans cet article, nous reprenons le débat sur la sociologie publique en nous inspirant de la sociologie féministe critique au Canada. Alors que nous félicitons l'effort de Burawoy de remettre dans son contexte la sociologie américaine et d'accueillir la mobilisation avec divers publics, nous examinons aussi quatre limites à son modèle. Premièrement, il ne reflète pas de manière adéquate la pratique de la recherche féministe qui relève de la sociologie interdisciplinaire et, à la fois, professionnelle, critique politique et sociale. Deuxièmement, il ne prend pas en compte la méthodologie féministe en tant que forme intégrative de sociologie. Troisièmement, il ne régionalise pas assez la sociologie américaine et n'aborde pas de quelle manière la sociologie « professionnelle » américaine peut représenter une menace plutôt qu'un porte-étendard au Canada. Quatrièmement, il manque des exemples concrets de sociologie publique et de sa manière d'être assumée dans des situations précises. Nous discutons brièvement de notre recherche pour illustrer la sociologie publique « organique » dans le contexte canadien. Mots clés : sociologie féministe critique, méthodologie féministe, sociologie canadienne, sociologie publique organique 


\section{INTRODUCTION}

A

s president of the American Sociological Association in 2004, Michael Burawoy initiated a lively discussion about the sociological terrain in the United States and appealed to his colleagues to engage in more "public sociology" (Burawoy 2004; 2005a). ${ }^{1}$ We applaud Burawoy's efforts to begin the task of contextualizing US sociology and of renewing the challenge to embrace rather than eschew engagement with various publics. In outlining his version of public sociology, Burawoy has provided complex, thought-provoking if ambiguous conceptualizations that have led to vigorous debate and examination of core terms. In this paper, we aim to contribute to the debate by discussing feminist sociology, particularly in Canada.

Since only a few commentators on Burawoy's model have engaged with feminist sociology (e.g., Acker 2005; Brewer 2005; Lal 2008; Risman 2006), we are grateful that the editors invited us to participate in this journal issue. ${ }^{2}$ Though Burawoy acknowledges that feminist sociology is a public form of sociology, he has not very fully engaged with it. His analysis can be strengthened by attending more to the "feminist critique and to the complex involvement of gender in the issues he discusses" (Acker 2005:327) and to the specific ways that feminist sociology intersects with the four types of sociology he identifies.

In this paper, we suggest, first, that in highlighting "professional" sociology as the core of sociology in his four-fold typology, Burawoy does not adequately reflect the practice of feminist and interdisciplinary research. Second, we consider how feminist epistemologies provide an example of an integrative form of sociology that eschews both sharp disciplinary divisions and distinctions between professional, critical, public, and policy knowledge production. Third, we locate our critique explicitly within Canada's educational and research context to illustrate the importance of national differences in assessing Burawoy's model, of "provincializing" US sociology, and of considering how American "professional" sociology can operate as a threat rather than a standard-bearer. Fourth, while critical of Burawoy's specific version of public sociology, we appreciate its potential for rekindling central epistemological debates within sociology and for acknowledging and legitimating public sociology. To that end, we discuss several of our research projects that serve as illustrations of specific forms of "organic" public sociology. We re-

1. For discussions see, for example, http://burawoy.berkeley.edu/PS.htm retrieval date December 5, 2008.

2. We would also like to thank the co-editors of this special issue, Rick Helmes-Hayes and Neil McLaughlin, for their very useful comments on an earlier draft of this paper. 
flect on some of the complexities of our collaborative research and show how it is simultaneously professional, critical, policy, and public sociology. This model of research, inspired by feminist and other progressive movement epistemologies, does not separate morality, politics, social justice, and social change from the practice of professional sociology. We hope that examples of our engaged research will give Burawoy's notion of public sociology more clarity and substantive meaning within a framework of critical feminist sociological practice.

\section{Michael BuRawoy's Typology of Sociology}

Burawoy divides sociology into four distinct types - professional, critical, public, and policy - distinguished by audience (academic versus nonacademic) and forms of knowledge (instrumental versus reflexive) (2005a:269). Many commentators have noted that these central concepts anchoring his discussion are useful but ambiguous (e.g., Acker 2005; Brewer 2005; McLaughlin and Turcotte 2007). As feminist sociologists who engage in forms of public sociology, we are concerned about the ambiguities of these concepts. In branding professional sociology as "instrumental academic" research, Burawoy elevates it above all other forms in his typology as the core of the discipline, contrary to his own efforts to challenge this hierarchy of evaluation. Professional sociology, he writes,

provides legitimacy, expertise, distinctive problem definitions, relevant bodies of knowledge and techniques for analyzing data. An effective public or policy sociology is not hostile to, but depends upon the professional sociology that lies at the core of our disciplinary field. (Burawoy 2004:1609)

An implication of his analysis is that " "good' research is only done in the sphere of professional sociology" (Acker 2005:330) and that this sociology leads the other sociologies: "only professionally oriented, disengaged research is conducted with rigour and is capable of yielding methodological and theoretical innovation" (McLaughlin et al. 2005:137). Read through a much earlier critique of trends in US sociology that included pleas for critical public engagement, Burawoy's professional sociology brings to mind the categories of abstracted empiricism and grand theory that C. Wright Mills (1959) so trenchantly critiqued and that most feminist theories and methodologies have sought to overcome. In addition, despite his efforts to provincialize US sociology, Burawoy's $2 \times 2$ table can be interpreted as a Parsonian-type model that intends to 
apply to sociology everywhere while most closely reflecting a particular kind of US sociology. This form of US sociology is formalistically professionalized, especially at the more elite research universities (McLaughlin and Turcotte 2007) - as distinct from being "professional" and results in institutionalized practices that are unnecessarily rigid and exclusionary. Rather than using this model to prescribe what sociology should be, McLaughlin and Turcotte (2007) usefully argue that it should be turned into empirical, researchable questions that determine the size and influence of each type of sociology within different disciplinary, institutional, and national contexts.

As feminist sociologists, we are also concerned about other problems of interpretation in Burawoy's typology. Burawoy characterizes each ideal type as a division of labour that exists, normatively, in reciprocal interdependence. He suggests that most sociologists concentrate their efforts in one type although he grants that they may simultaneously inhabit more than one of the cells or change from one to another over their careers. While allowing for internal complexity of each type (e.g., professional sociology can be reflexive at times, not just instrumental) and for permeable boundaries between the four types, Burawoy's model can be interpreted as overly bounded, static, and nonvariable. It does not appear, for example, to adequately account for such multidisciplinary fields as social gerontology (Putney et al. 2005) or feminist sociology in which the distinctions between professional, critical, policy, and public domains are blurred. In attempting to integrate sociology and legitimate public sociology, Burawoy glosses over the contradictions and tensions between the four types he identifies, particularly vis-à-vis the longstanding methodological feuds between positivism, critical theory, and postpositivism (cf. Lal 2008).

As feminists aware of sociology's history of exclusions in the production of knowledge, we are wary of hierarchies that Burawoy's typology may initiate or reproduce that rest on a narrowly cast US version of professional sociology. In contrast to his concept of professional sociology as an engagement with specific social theories (that are not critical) or with a limited range of methodological approaches to research (that are neither reflexive nor involve publics or policymaking), we suggest looking for a more inclusive definition. A more inclusive definition of professional sociology might, for example, involve particular credentials (a graduate degree in sociology) and the undertaking of specific activities (such as teaching sociology in a university or college and/or engaging in rigorous ethical research and publishing). This definition embraces a diversity of orientations, methods, institutional locations, and public and policy engagements. 
Equally important, however, is the fact that Burawoy's identification of four distinct forms of sociology is itself questionable. As Ericson (2005) notes, sociology is (or perhaps should be) simultaneously professional, critical, public, and policy relevant. Whether or not sociology does or should take these forms simultaneously, and how such research is undertaken, requires discussion and empirical investigation. As part of this process, we describe below our research to provide examples of the simultaneous undertaking of professional, critical, policy, and public sociology.

We also take issue with the Gramscian separation of the distinct spheres of state, economy, and civil society that underlies Burawoy's discussion. In sharply dividing the subject matter of the cognate fields of political science, economics, and sociology - with their respective attention to the state, market, and civil society - his model ignores the growth of interdisciplinary research in which many of us have long engaged.

Interestingly, this division also entirely ignores other disciplines, such as anthropology, for which a parallel debate (the call for more public anthropology) predates by several years Burawoy's intervention (for example, in Chicago in 1999, the topic of the American Anthropological Association forum was Public Anthropology). ${ }^{3}$ As Calhoun argues, rather than reinforcing disciplinary boundaries and social dichotomies, "we should be arguing that state and market are social" (2005:361).

Burawoy's model tends to demonize the state (and policy intervention/state reform) as well as the market, while romanticizing civil society (including giving it a progressive spin). This ignores both the multisited institutional locations of sociological research and the complex interplay between fields of power, agency, and social change. Feminist theorizing shows that civil society is a complex concept that consists of both the public and the private spheres structured as male-dominated, with the private often disappearing in discourse on civil society (Acker 2005). Burawoy's focus on civil society can be interpreted as reinvoking the public and private dichotomy of Western societies that has been the subject of so much feminist critique, especially in its argument that family and community life (sites of civil society) cannot be understood as separate from political and economic spheres. Significant feminist theory and research have made a concerted effort to argue for a reconceptualization of these spheres acknowledging their interpenetration, rather than isolation from one another.

Where we are in fundamental agreement with Burawoy is in locating the central questions for assessing the state of sociology in the US, Can-

3. See, for example, Borofsky 2000; 2008; Purcell 2000; Lassiter 2008. 
ada, and elsewhere by asking "sociology for whom?" and "sociology for what?" These questions require reflexivity that positions social theories, research methodologies, and indeed researchers within contexts of power and social location. Burawoy designates critical and public sociology as inherently reflexive in contrast to professional and policy sociology. Defining reflexivity, however, is no simple task. According to Burawoy (2004:1606), reflexive knowledge is communicative action that aspires to a dialogic character, "although mutuality and reciprocity are often difficult to achieve in practice." Reflexivity involves value discussion concerning the ethical goals for which research may be mobilized and stimulates public discussions about the possible meanings of the good society. Recent feminist epistemological debates have been particularly fruitful in contributing to and expanding upon critical theory's understanding of reflexivity. Critical feminist sociological debates, informed especially by engagement with extra-academic communities concerned about social justice for socially marginalized groups, have helped to shape our research.

\section{Taking Feminist Methodology into Account}

Feminist sociology is part of a broad enterprise of feminist theorizing and research. It is inherently interdisciplinary, emerging through crossdisciplinary debates, research, and pedagogies. Burawoy includes fleeting acknowledgement of feminist work as part of critical sociology, and the study of sex and gender as particularly focused on public sociology. He writes, for example, that "public sociology has been the transmission belt of the civil rights and women's movements that have transformed professional sociology" (2004:1611). In light of his mission to carve out a larger space for publicly engaged sociology, Burawoy's lack of serious attention to feminist work is surprising, although not without explanation (see Lal 2008).

Feminist sociology, while diverse, has been shaped by critical theory that aims to be reflexive and contextual stemming from the fundamental premise that knowledge, being socially embedded, is always political (Harding 2004; Ramazanoglu and Holland 2002). This critical feminist approach contends that the detached objectivity common in the research Burawoy defines as professional should be regarded instead as socially located, socially invested, and politically informed. As Haraway (1991) argues, research generates a variety of situated knowledges; the universalistic view of everywhere from nowhere, or the God trick, is at best an illusion. There are no uninterested/unlocated/apolitical knowers. 
One might reflect, for example, on how Burawoy's antagonism towards the state and his call for sociology to focus on civil society is situated within contemporary US politics that - at least before Barack Obama's run for President breathed new passion into the electoral system - offered little hope for state-initiated progressive social change. In contrast, while the past twenty years have been challenging for the feminist movement, as feminist sociologists working in Canada, we can nevertheless reflect back on what was arguably one of the more vital and successful feminist movements in Anglo-western countries from the early 1970s to the early 1990s (cf. Cohen and Pulkingham 2009; Rebick 2005; Brodie 2007). And though the history of this movement encompasses an oftentimes difficult and conflictual relationship with the state, at the same time, we see this engagement as both necessary and dialectically productive of knowledge and social transformation. One measure of the movement's success is Canada's leadership until recently within Anglo-western countries "in the development of policies and agencies designed to enhance the status of women in all sectors of society and to provide them with points of entry into the policy-making process" (Brodie 2007:167).

The contextualization of feminist scholarship means locating research in particular national locations and institutional contexts, a process recalled in Burawoy's invocation to provincialize American sociology or, as Inglis suggests more pointedly, "to recognize its [existing] "provincialism"' (2005:385). Taking social location seriously, however, means more thoroughly interrogating how location is structured through various relations of power and privilege, a central part of answering "sociology for whom?" Feminist sociologists like Dorothy Smith (1987) have long pointed out that the answer for most "malestream" sociology is "sociology for men." Her work to recraft a "sociology for women" is part of a larger interdisciplinary enterprise to re-embody knowledge production. Some feminist sociologists, such as Patricia Hill Collins (1990; 2004), have developed a more complex and explicitly intersectional sociology attentive to a range of differences in material conditions and subjectivities including, but not limited to, the way intersections of race, gender, sexuality, and class shape "knowledge for whom." Others have drawn from Aboriginal and postcolonial scholars' attempts to decolonize methodologies (such as Linda Tuhiwai Smith 1999) and interrogate colonial/postcolonial relations embedded in knowledge production within colonially derived nations (including the United States and Canada) and between peoples of the global north and south which remain shaped by US hegemony (e.g., Mohanty 2004). Sociological research informed by such postcolonial, intersectional, and/or feminist-materialist perspec- 
tives spans academic audiences and other publics, but is largely absent from Burawoy's framing of socially engaged research and its publics.

Burawoy's second question - "sociology for what?" - has also been pivotal to the development of feminist sociology. Like other transformative social theories, feminist research has multiple and simultaneous roots in academe and in broader social movements that nurture each other in often uneasy and conflicted ways. Not unlike the Marxianinspired postulate that the point is not just to understand the social but to change it, feminist research, recognizing gender inequalities, is generally concerned with social change. The relationship between academic feminisms and community-based forms of feminist activism is neither seamless nor without antagonisms, but remains a point of ongoing contact in most societies. This emphasis on transformative research has arguably produced strong links between academic feminist sociology and what Burawoy defines as public and policy sociology. Writing in the US context, Barbara Risman (2006:281, 283) argues that "feminist sociologists have always been public sociologists" since "feminists always frame academic scholarship around a mission of social justice." In the Canadian context, feminist sociology in the academy is closely intertwined with policy (including government-contracted research) and publics (various types of public and nonprofit, nongovernmental organizations and grass-roots community groups) in formative and ongoing ways that challenge the four-fold distinction at the heart of Burawoy's model of sociology.

In an era where US vice-presidential candidate Sarah Palin raised new questions about how broadly the term feminist might be framed, we need not assume that all feminist sociologists subscribe to epistemological positions of critical theory or align themselves with progressive social change framed by social justice issues. However, these extensive theoretical and methodological debates, informed by critical theory and connected to specific publics, especially progressive social movements, have resulted in significant frameworks that shape feminist sociology.

\section{Locating Ourselves within Canada}

Sociology developed differently in Canada than in the United States (Brym and Fox 1989). In part, this difference is connected to Canada's location beside a powerful nation, with a population ten times larger that continues to exert hegemony in intellectual matters as in other spheres. Sociologists played a prominent role in the "Canadianization movement" in the 1970s and 1980s, which promoted Canadian-defined re- 
search trajectories and jobs for Canadian scholars, as a form of resistance against US intellectual domination (Cormier 2004; McLaughlin 2005). Canadian sociology continues to be more strongly influenced by European sociology, the latter carrying on the tradition of its intellectual foreparents for whom praxis - in which the validation of theory is assessed in how it informs action - was highly valued (Purcell 2000). Thus Canadian sociology produces a larger proportion of research that fits under Burawoy's critical sociology, including particularly well-developed traditions of Canadian political economy (McLaughlin and Turcotte 2007) and feminist sociology that are simultaneously more critical and linked to social change (heavily influenced by materialist, intersectional and postcolonial feminisms) than south of the border (Eichler 2002).

As Burawoy (2005b:427) notes, the increasing pressure in most countries (including Canada) to benchmark disciplinary standards set by US journals (which is another means of elevating an exclusionary and hyper-professionalized sociology above all other forms) is "a disaster for national sociology in general and for public sociology in particular." In the Canadian context, this external pressure narrows the notions of excellence in sociology departments and particularly affects younger scholars working in more critical traditions, pursuing substantive Canadian topics, or even taking graduate studies at a Canadian university, raising questions about the long-term effectiveness of the Canadianization movement in sociology. While preference for "equally qualified" Canadian applicants continues to appear in job advertisements, in some institutions it has become increasingly difficult for non-US-educated scholars to get jobs. To take the example of one western Canadian university, of the seven searches in sociology in the last four years - a critical period of regeneration that will shape research and teaching for decades to come - all appointed candidates were US-educated at the $\mathrm{PhD}$ level, and all but one was a US citizen when hired. In most of these competitions only US-trained scholars made it to the short-list. In this context of ongoing US intellectual hegemony, a model of sociology that carves out separate and unequally valued professional, critical, policy, and public knowledge production is highly problematic, especially since this model does not reflect universal principles, but instead historical US contingencies. As Calhoun (2005) notes, during the growth of the political Right in the past few decades, especially in the US, formalistic notions of how science works have gained ascendancy and such public institutions as universities have become endangered. Correspondingly, sociology has become less critical and more "domesticated."

While these institutional changes have occurred in Canada too, the context within which Canadian sociologists conduct research is signif- 
icantly different both from the US postsecondary educational and research environments. By and large, Canadian universities are still public institutions. This fact has a number of ramifications. One is that, perhaps in contrast to research undertaken in private universities, public-based researchers, largely funded by public dollars, feel increasingly obliged to demonstrate to the public the importance of their research and scholarly activities. For example, in the late 1990s in British Columbia (where all the authors of this article are located), the Confederation of University Faculty Associations of British Columbia (CUFA BC) amended the terms of an existing award (Academic of the Year Award) and created a new academic award (Career Achievement Award) to specifically recognize professors who have distinguished themselves through university research and scholarly activity that contributes to the nonacademic community. ${ }^{4}$

More importantly and directly, since the turn of the millennium, a federal government-funded research infrastructure has emerged that facilitates forms of public sociology. The Social Sciences and Humanities Research Council of Canada (SSHRC) is the long-standing and dominant source of peer-reviewed research funds for academic sociologists in Canada. In recent years SSHRC has created specific funding programs to build research links between academics and communities of various sorts. Some of the SSHRC programs to which sociologists often apply include $^{5}$ : Centres of Excellence for research on immigration and integration (Metropolis); Major Collaborative Research Initiatives (MCRI), an issue-driven funding program that, among other things, promotes interdisciplinary research and the development of active partnerships with private or public sector groups; Community-University Research Alliances (CURA) that promote an equal partnership between postsecondary institutions and public or private community and voluntary organizations; and special calls for research with Aboriginal communities. Another funding source is the Canadian Institute of Health Research (CIHR), the main body that funds health research, which also embraces an academic-community partnership model.

All these funding initiatives are premised on linking academic and "community-based" research. These government-supported programs in Canada help to realize the public sociology that Burawoy is keen to

4. http://www.cufa.bc.ca/index.php?option=com content\&task=section\&id=6\&Itemid= 32; retrieved November 1, 2008. Recipients of the award span the academic disciplinary spectrum, and include, among others, an anthropologist, archivist, botanist, climate scientist, ethnobotanist, historian, legal scholar, mathematician, poet, and sociologist.

5. There are a number of SSHRC strategic awards for other (and specific) disciplinary areas, such as management, finance, and administration, that focus, for example, on knowledge mobilization to nonacademic audiences. 
promote. Though these programs do not necessarily support progressive research for social change, they allow for it and often have direct connections to policy. To be more specific, for example, the Metropolis Centres institutionalize links between academics, government policy makers, and community formalized through funding partnerships between SSHRC and various government departments (including Citizenship and Immigration Canada, Heritage Canada, Canada Housing and Mortgage Corporation, and Status of Women Canada among others). In addition, the CURAs provide the opportunity to institutionalize partnerships between academics and community-based research organizations by allowing the nonacademic partners to direct or co-direct the project, and to administer research funds. ${ }^{6}$ Although most SSHRC-funded CURAs follow the traditional academic research model of housing the research funds with the university institution where the academic director/codirector is located, a couple of the CURAs have bucked this trend. One such CURA (described in more detail below) is the Economic Security Project (ESP). One of its principal investigators is a faculty member at Simon Fraser University and the other is the director of the Canadian Centre for Policy Alternatives (CCPA, BC Office); the SSHRC research funds are channeled directly to the CCPA (community) partner organization for administration and oversight.

Whether or not public and policy sociologists in the US are really as detached from professional and critical sociology as Burawoy implies, this is not the case in Canada. At the same time, we are not suggesting that Canada's academic-community partnership model satisfies all concerned or that it ideally engages with publics, or that it is not subject to internal debates and ongoing threats of funding cuts. For example, there is a long-standing concern among feminist researchers, within and beyond the academy, about the way government-funded research can co-opt research agendas and circumscribe what is researchable, who is researched, and how the research should be done. For good reason, Burawoy's model of public sociology is wary of state and market encroachment. In neoliberal times, in particular, strings attached to state funding can serve to domesticate sociology to serve dominant structures of power under the guise, for example, of the nebulous tax payer, rather than citizens of civil society.

Nonetheless, the state is not a monolith; its forms differ across nations, have localized impact and change historically. In Canada, this recent, institutional research context, based on peer-review, has allowed

6. As long as the community-based organization applies for and is granted institutional eligibility with SSHRC and signs a Memorandum of Understanding (MOU) on the Roles and Responsibilities in the Management of Federal Grants and Awards. 
feminist research to move back and forth across so-called professional, critical, policy, and public sociology, and indeed, inhabit all at the same time.

Until very recently, ${ }^{7}$ Status of Women Canada (SWC) was an important source of feminist research; it commissioned academic researchers to undertake specific studies, nurtured in-house researchers, and consulted widely with community groups. SWC research has been central to documenting the changing position of women in Canadian society and its research is widely used and produced by academically based sociologists. This policy-based research developed policy options with other government departments such as justice, health, immigration, Aboriginal affairs, and the labour market that not infrequently shaped new legislation. SWC research has also been explicitly linked to publics outside of government and universities, especially with organizations that form part of the women's movement in Canada.

For example, before funding cuts (engineered by neoliberal and neoconservative concerns) undermined its survival, the National Action Committee on the Status of Women (NAC), for decades the main umbrella organization of women's groups across the country, engaged in both research and policy consultations with SWC. At various times academically based feminists, some of whom are sociologists, have been heavily involved with NAC, even holding top leadership positions. The Canadian Research Institute for the Advancement of Women (CRIAW) is yet another venue in which feminists from academe, government, and community groups regularly work together to produce engaged scholarly research simultaneously geared toward professional critical analysis and public policy interventions.

Similar public bodies exist within Quebec - and to a lesser and more variable extent in other provinces - that link francophone feminist sociologists with activists and the provincial government. The institutional relationships between feminist researchers within government (or "femocrats"), those located within sociology and other departments in Canadian universities, and diverse community-based activists facilitate linkages across, rather than divisions between, Burawoy's types of sociology. ${ }^{8}$ However these academic-community-government partnerships

7. Since 2007, Status of Women Canada has effectively been gutted under the government of Stephen Harper. Its budget has been slashed, virtually eliminating its research capacity, and its ability to fund community-based groups has been compromised by a government mandate that prevents funding any group involved in advocacy.

8. Nor are these linkages unique to feminist sociologists. Well-known sociologists in Canada who Burawoy might describe as professional also have strong research links with Statistics Canada that include authoring papers on a wide variety of topics that may also be published in traditional academic venues. 
proceed in Canada, their existence calls into question a universalizing model of sociology that does not sufficiently account for such practices.

\section{Creating a more Engaged and Collaborative Sociology}

We wholeheartedly endorse Burawoy's desire to generate in the US more public sociology, a term we understand to include diverse forms of community-based research, broadly interpreted, that grapple with contemporary social issues. In our view a central question is not whether we should be socially and politically engaged through our research - we already are whether we acknowledge it or not - but how we can do this most effectively (cf. Putney et al. 2005). Valorizing work with communities/ publics while denigrating policy-intervention/state reform is the least helpful way to accomplish this. Rather than posit the separation of state, market, and civil society, leaving sociologists to consult with invested publics in civil society, ${ }^{9}$ we suggest shifting the focus to governance and the exercise of power in all social realms. Civil society, for example, is itself a contested site of governance, in which collaborative and reflexive research with different publics can point to new forms of resistance, accommodation, policy interventions, and sociological theorizing.

We have undertaken specific forms of "organic" public sociology that are shaped by our interests as critical feminist sociologists. The defining features of our research were: interdisciplinary, state-funded, engaged with community groups that are socially marginalized, collaboration with community members, shaped by critical feminist theoretical and methodological perspectives, and published in academic, policy, and public venues. These characteristics allow the organic public sociology described by Burawoy: "the sociologist works in close connection with a visible, thick, active, local and often counter-public" (cited in Brint 2005:47). In discussing these collaborative studies, we are not suggesting that this work is unusual or exemplary - many Canadian feminist sociologists engage in similarly collaborative interdisciplinary work. Our aim is to provide concrete examples with which we are familiar, to show how they exist within an institutional and community environment that enables academics to engage in public sociology that is simul-

9. Burawoy takes this argument even further in his 2006 article "A public sociology for human rights" where it seems that professional monopoly is one of the driving motivations behind his attempt to establish civil society as the exclusive object of study for sociology. While we share a concern and frustration with the disciplinary ascendency of economics and political science in relation to government and market domains, we do not share Burawoy's solution to this problem. 
taneously professional, critical, policy sociology. In the conclusion, we briefly reflect on some of the challenges of our research endeavours.

All three authors of this article have received one or more SSHRC research awards through Metropolis, MCRIs, and/or CURAs ${ }^{10}$ that link critical, public, and policy research. In a Metropolis-funded study, Gillian and Arlene began with a longitudinal research design of interviewing immigrant families and their settlement patterns over several years (e.g., Creese, Dyck and McLaren 2008). As Gillian became familiar with study participants' experiences, she developed new research questions and a collaborative relationship with one of the participants; this collaboration led to another study that focused on how the "colour of English" shapes access to employment and belonging in Canada for African women (Creese and Kambere, 2003) and a new SSHRC project that explored settlement and belonging among women and men from diverse countries in sub-Saharan Africa (Creese 2007; Creese and Wiebe forthcoming). The research process transformed the relationship between researcher and participant into a collaboration that grew to include other community-based researchers in the local African community, and helped provide credible data that were successfully used to get funding for a new settlement organization run by and for immigrants and refugees from sub-Saharan Africa (Umoja Operation Compassion Society/African Family Services). In turn, ongoing collaboration with Umoja has led to a new Metropolis-funded study to address an issue of special concern to the community - the challenges facing African youth in the Vancouver area. These research projects involved community-based researchers and simultaneously produced professional, critical, public, and policy-relevant sociology that appears in academic venues, community-based funding proposals, research forums, and, through $\mathrm{Me}$ tropolis, working papers directed at policy makers in Ottawa, BC, and local municipal governments.

The research that Arlene and Jane have conducted in collaboration with the Canadian Centre for Policy Alternatives (CCPA) BC Office illustrates another form of public sociology connected to marginalized communities, but coordinated by an independent research institute concerned about social and economic justice issues. The CCPA brings together scholars from a range of disciplines including political science, economics, sociology, women's studies, geography, environmental studies, and psychology in collaborative relationships with CCPA staff and volunteers, community-based researchers, community organizations,

10. The research described in this article pertains to one Metropolis and one CURA award that the authors are engaged in, it does not describe the MCRI and another (different) CURA award that one of the researchers is involved in. 
and labour unions. This nonprofit organization produces critical professional social science research disseminated through policy documents, mainstream and alternate media (press releases, press conferences, and newspaper opinion pieces), and community outreach alongside more traditional academic publications. In its current project on economic security, funded by SSHRC through the highly competitive CURA research grants, the CCPA has coordinated 20 academic collaborators (from 4 universities) and 24 community group partners (plus other scholars and community members) who work together in research teams on a range of studies in the three streams of welfare, health, and employment. This collaborative research allows for multiple public involvements in the exploration of intertwining social relations in the state, the market, and civil society. To illustrate, we briefly describe two recent studies; Arlene was a co-principal investigator in one and Jane was a co-principal investigator in the other.

The first example, Cultivating Farmworker Rights (Fairey et al. 2008), examined the impact of employment policy on immigrant and migrant farmworkers. This study involved academics and students in several different disciplines (sociology, school of business, Latin America studies), union researchers, community-based service workers, and grass-roots community activists. CCPA staff members were also actively involved. One result of this collaboration is that the research team engaged in a form of participatory action research with the grass-roots community activists and migrant workers to determine the purposes and outcomes of the inquiry. Because of the complexity of the issues, the study focused on how power was structured in various sites that straddled the state, the market, and civil society. It was necessary, for example, to determine how government policy (at federal, provincial, and municipal levels) worked in conjunction with employer interests to create "unfree" labour conditions. As a result of these conditions, the study found that farmworkers were unable to exercise not only their labour rights, but also their social, civil, and human rights. The research led to a wide range of recommendations that included: immigration policy; employment standards; health, safety, and housing regulations; labour contracts; and community advocacy - crossing the three spheres separated in Burawoy's discussion. The CCPA report was co-published with two local community agencies (Progressive Intercultural Community Services and Justicia for Migrant Workers) and the BC Federation of Labour. To reach out to relevant publics and contribute to social action, the CCPA (BC Office) circulated the report widely; it also distributed summaries of key findings and recommendations in Punjabi and Spanish. It is difficult to assess the policy impact of such research. However, several months 
following the report's release, mobilizing among advocates and agencies to promote protections for migrant farmworkers and other temporary foreign workers led the provincial Employment Standards Branch to create an informal task force for investigating Temporary Foreign Workers Employment Standards claims.

The second CURA ESP-funded project example is Living On Welfare (Klein and Pulkingham 2008), a two-year study examining the impact of welfare rule changes on longer term "expected to work" welfare recipients. The study, conducted by a research team involving nonprofit community-based researchers (including a CCPA staff member) and academics (faculty and students in sociology, social work, and women's studies), documents a range of impacts, particularly those resulting from the stringent employment obligations and the welfare time limits implemented in 2002, on those who remained on assistance, those who left voluntarily, and those who were cut off assistance. The study concludes with a number of concrete policy recommendations pertaining to welfare, minimum wage, and employment provisions in the province. The study is a co-publication of the CCPA (BC Office) and Raise the Rates (www.raisetherates.org), a province-wide coalition of community groups and organizations concerned about poverty and homelessness in BC. As a form of advocacy research, the study draws upon and contributes to existing antipoverty coalition mobilization efforts in the province - coalition mobilization efforts that, during the course of the study, did see the province back-track on some of the most deleterious welfare rule changes, and increase welfare benefits. ${ }^{11}$

\section{Conclusion}

These examples illustrate the specific ways our research undertook simultaneously professional, critical, policy, and public sociology within a framework of critical feminist sociological practice concerned with progressive social change. Our professional research - recognized by peer-reviewed funding bodies and publication venues - was informed by, rather than separate from, critical theories. Critical theoretical concerns about power, privilege, inequality, and marginality provided us with analytic frameworks and methodologies for exploring social justice

11. Knowledge dissemination for the two ESP projects described here includes published research reports intended to be accessible by nonacademic and academic audiences (available in print and on the web), academic conference presentations, press conferences and media releases (targeting mainstream and alternate print, electronic and television media), and anticipated peer-reviewed publications. Both authors also have peer-reviewed academic publications stemming from their involvement as co-investigators on other ESP projects. 
issues. Our policy research did not fit Burawoy's description of work that aims to solve a problem defined by clients or that is sold for a fee. Instead, our research consisted of independent policy analysis that intersected with community mobilizing efforts. An enabling institutional and community environment, within a specific national context, helped make this kind of research possible.

The research described here, inspired by feminist and other progressive movement epistemologies, does not separate morality, politics, social justice, and social change from the practice of professional sociology. Like Burawoy (2006), we believe that social justice is a fundamental value that should be brought closer to the core of sociology with a corresponding concern about devastating world problems. There are those who worry about encouraging a larger role for critical sociology and activism and the pernicious effects of a renewed focus on social justice (e.g., Brint 2005; cf. Turner 2005). In contrast, we are more concerned about exclusions in sociology and the inattention to values and politics that hold sway. Like Risman (2006:290), we think it is worth posing the question whether public sociology "must have a central shared ideological mission." The debate this question provokes is an important one because it requires that we pay attention to the role of values and politics.

In addressing these issues, nonetheless, collaborative and engaged models of sociology are faced with challenging questions, including the balance of scholarship and advocacy; the mutuality and reciprocity of collaborative research among "unequals"; the ability to be truly reflexive; and the definition of relevant communities and publics. Rather than relegating questions about values and politics to the sidelines, critical feminist sociology places their inherent tensions with ideals and norms about disinterested science at the core. This approach allows for the critical gaze to turn in multiple directions: not only on society, the foundations of the discipline, and the practice of the critical theorist, but also on the values and politics of collaboration itself and of the social movements and marginalized groups involved. Such reflexivity does not merely stem from the discipline however; its origins may come from community-based practices and politics. The Combahee River Collective 1977 document that inspired the theorizing of Black feminist sociologists in the US, for example, recognized the importance of reflexivity:

In the practice of our politics we do not believe that the end always justifies the means. Many reactionary and destructive acts have been done in the name of achieving 'correct' political goals. ${ }^{12}$

12. http://iambecauseweare.wordpress.com/roots-and-wings-the-combahee-river-collective-statement/; retrieved December 6, 2008. 
Such self-reflexivity suggests that sociology "is not ahead of the game" but has much to learn from "the portals of struggle" (Brewer 2005:355; cf. Katz-Fishman and Scott 2005).

We are grateful to Burawoy for opening up this discussion, but are concerned about the universalizing and ahistorical tendencies of his model that reinforce the hegemonic positioning of a hyper-professionalized US sociology vis-à-vis the rest of sociology and other national contexts. To be sure, the wide-ranging and sophisticated nature of Burawoy's analysis includes major qualifications on this model. Burawoy writes, for instance, that "we need a new public sociology that brings together state, economy, and society; that draws on different disciplines; and that is not bound by the nation-state" (2006:2). While we agree with this emphasis, we do not see it as particularly new; and neither would Burawoy, we suggest, if he acknowledged more than in passing the vibrant and transformative traditions aligned with feminist sociology that provide a different model of professional critical sociology that engages with diverse publics and social policies.

In contrast to the individual scholar implicit in Burawoy's model, who maintains the fortress of a hyper-professionalized sociology, collaborative models of feminist sociological practice reach out to other disciplines and/or various publics. By critically engaging with social theory, publics, and policy in the quest for rigorous research findings, sociologists can inform public debate about key social issues that concern various communities, including marginalized ones. As Calhoun (2005:358) notes, sociologists need to worry about what we study, and to take "public significance into account in problem choice." Working with community social justice groups is one way for sociologists to fulfill their responsibility to study socially significant phenomena. We are not suggesting that this collaborative model become orthodoxy or a template for all sociological research. Instead, we are pointing out that in contrast to Burawoy's 2 x 2 model, we need to consider other possibilities that exist, particularly in different disciplinary, institutional, community, and national contexts. By considering examples of critical and collaborative research, it becomes more possible to consider what public sociology is and how it can be done. This collaborative model provides a vigorous form of sociology that grounds research in local reality (Inglis 2005) and avoids the pitfalls of abstracted empiricism and grand theory that feed into the US quest for hegemony and haunt Burawoy's attempt to find an alternative. 


\section{REFERENCES}

Acker, Joan. 2005. Comments on Burawoy on public sociology. Critical Sociology 31(3):327-331.

Brewer, Rose. 2005. Response to Michael Buroway's commentary: "The critical turn to public sociology." Critical Sociology 31(3):353-359.

Brint, Steven. 2005. Guide for the perplexed: On Michael Burawoy's 'public sociology.' The American Sociologist 36(3-4):46-65.

Borofsky, Robert. 2000. Public anthropology. Where to? What next?" Anthropology News 41(2):9-10.

2008. Public anthropology (A personal perspective). http://www.publicanthropology.org/Defining/publicanth-070ct10.htm. Date retrieved: November 7, 2008.

Brodie, Janine. 2007. Canada's three ds: The rise and decline of the gender-based policy capacity. Pp. 166-84 in Marjorie Cohen and Janine Brodie. eds., Remapping Gender in the New Global Order. London: Routledge.

Brym, Robert and Bonnie Fox. 1989. From Culture to Power: The Sociology of English Canada. Toronto: Oxford University Press.

Burawoy, Michael. 2004. Public sociologies: Contradictions, dilemmas, and possibilities. Social Forces 82(4):1603-1618. 2005a. American Sociological Association Presidential address: For public sociology. British Journal of Sociology 56(2):259-294.

2005b. Responses: Public sociology: populist fad or path to renewal? British Journal of Sociology 56(3):417-432.

2006. A public sociology for human rights Pp. 1-18 in Judith Blau and Keri Iyall Smith, eds., Public Sociologies Reader. Lanham, MD: Rowman and Littlefield.

Calhoun, Craig. 2005. The promise of public sociology. British Journal of Sociology 56(3):355-363.

Cohen, Marjorie Griffin and Jane Pulkingham. 2009. Introduction: Going too Far? Feminist public policy in Canada. Pp. 2-48 in Marjorie Griffin Cohen and Jane Pulkingham, eds., Public Policy For Women: The State, Income Security and Labour Market Issues. Toronto: University of Toronto Press.

Collins, Patricia Hill. 1990. Black Feminist Thought. New York: Routledge.

2004. Black Sexual Politics: African Americans, Gender and the New Racism. New York: Routledge.

Cormier, Jeffrey. 2004. The Canadianization Movement: Emergence, Survival and Success. Toronto: University of Toronto Press.

Creese, Gillian. 2007. From Africa to Canada: Bordered spaces, bordered crossings and imagined communities. Pp. 348-381 in Vijay Agnew, ed., Interrogating Race and Racism. Toronto: University of Toronto Press. 
Creese, Gillian, Isabel Dyck and Arlene Tigar McLaren. 2008. The 'flexible' immigrant? Human capital discourse, the family household and labour market strategies. Journal of International Migration and Integration 9(2):269-288.

Creese, Gillian and Edith Ngene Kambere. 2003. What colour is your English? Canadian Review of Sociology and Anthropology 40(5):565-573.

Creese, Gillian and Brandy Wiebe. Forthcoming. Survival employment: Gender and deskilling among African immigrants in Canada. International Migration.

Eichler, Margaret. 2002. Feminism and Canadian sociology. The American Sociologist 33(1):27-41.

Ericson, Richard. 2005. Publicizing sociology. British Journal of Sociology 56(3):365-372.

Fairey, David, Christina Hanson, Glen MacInnes, Arlene Tigar McLaren, Gerardo Otero, Kerry Preibisch, and Mark Thompson. 2008. Cultivating Farmworker Rights? The Impact of Changes to Employment Regulation on Immigrant and Migrant Farmworkers in British Columbia. Vancouver: The Canadian Centre for Policy Alternatives - BC Office, Progressive Intercultural Community Services Society, Justicia for Migrant Workers and the BC Federation of Labour.

Haraway, Donna. 1991. Situated knowledges: The science question in feminism and the privilege of partial perspectives. Pp. 183-201 in Donna Haraway, Simians, Cyborgs and Women. New York: Routledge.

Harding, Sandra. 2004. Rethinking standpoint epistemology: What is 'strong objectivity'? Pp. 39-64 in Sharlene Nagy Hesse-Biber and Michelle Yaiser, eds., Feminist Perspectives on Social Research. New York: Oxford University Press.

Inglis, Christine. 2005. Comments on Michael Burawoy's ASA Presidential Address. British Journal of Sociology 56(3):383-386.

Katz-Fishman, Walda and Jerome Scott. 2005. Comments on Burawoy: A view from the bottom-up. Critical Sociology 31(3):371-374.

Klein, Seth and Jane Pulkingham (with Sylvia Parusel, Kathryn Plancke, Jewelles Smith, Dixon Sookraj, Thi Vu, Bruce Wallace and Jane Worton). 2008. Living on Welfare in BC. Experiences of Longer-term "Expected to Work" Recipients. Vancouver: The Canadian Centre for Policy Alternatives - BC Office and Raise the Rates.

Lal, Jayati. 2008. On the domestication of American public sociology: A postcolonial feminist perspective. Critical Sociology 34(2):169-191.

Lassiter, Luke Eric. 2008. Moving past public anthropology and doing collaborative research. NAPA Bulletin 29:70-86. 
McLaughlin, Neil. 2005. Canada's impossible science: Historical and institutional origins of the coming crisis in Anglo-Canadian sociology. Canadian Journal of Sociology 30(1):1-40.

McLaughlin, Neil, Lisa Kowalchuk, and Kerry Turcotte. 2005. Why sociology does not need to be saved: Analytic reflections on public sociologies. The American Sociologist 36(3-4):133-151.

McLaughlin, Neil and Kerry Turcotte. 2007. The trouble with Burawoy: An analytic, synthetic alternative. Sociology 41(5):813-828.

Mills, C. Wright. 1959. The Sociological Imagination. New York: Oxford University Press.

Mohanty, Chandra Talpade. 2004. Feminism Without Borders: Decolonizing Theory, Practicing Solidarity. Durham: Duke University Press.

Purcell, Trevor W. 2000. Public anthropology. An idea searching for a reality. Transforming Anthropology 9(2):30-33.

Putney, Norella M., Dawn E. Alley, and Vern L. Bengtson. 2005. Social gerontology as public sociology in action. The American Sociologist 36(3-4):88104.

Ramazanoglu, Caroline and Janet Holland. 2002. Feminist Methodology: Challenges and Choices. London: Sage Publications.

Rebick, Judy. 2005. Ten Thousand Roses: The Making of a Feminist Revolution. Toronto: Penguin Canada.

Risman, Barbara J. 2006. Feminist strategies for public sociology. Pp. 281-292 in Judith Blau and Keri Iyall Smith, eds., Public Sociologies Reader. Lanham, MD: Rowman and Littlefield.

Smith, Dorothy. 1987. The Everyday World as Problematic: A Feminist Sociology. Toronto: University of Toronto Press.

Smith, Linda Tuhiwai. 1999. Decolonizing Methodologies: Research and Indigenous Peoples. London: Zed Books.

Turner, Jonathan H. 2005. Is public sociology such a good idea? The American Sociologist 36(3-4):27-45.

Gillian Creese is the Director of the Centre for Women's and Gender Studies, and a Professor in the Department of Sociology at the University of British Columbia. Her research interests include women and trade unions, feminist research methods, and immigration and settlement issues in Canada, with a particular focus on immigrants from sub-Saharan Africa. She is a Research Affiliate of Metropolis BC, and the President of the Board of Umoja, a settlement organization serving immigrants and refugees from sub-Saharan Africa. creese@interchange. $\underline{\text { ubc.ca }}$

Arlene Tigar McLaren is Professor Emerita in the Department of Sociology and Anthropology at Simon Fraser University. Her recent research has examined traditional schools and school choice, home support services and restructuring, 
employment standards policy and im/migrant farmworkers, immigration policy and parental sponsorship, immigrant family integration and belonging, traffic safety and automobility. She is a Consulting Editor of the Canadian Review of Sociology, Research Affiliate with Metropolis BC, and Research Associate of the Canadian Centre for Policy Alternatives. arlene_mclaren@sfu.ca

Jane Pulkingham is Chair and Professor of Sociology, Department of Sociology and Anthropology at Simon Fraser University. Her current research and teaching focuses on: gender, inequality and welfare state restructuring; lone mothers and welfare reform; health, citizenship and the medicalization of welfare; income security and labour market policy; poverty studies; gender and family law. She is a research associate and research advisor with the Canadian Centre for Policy Alternatives BC Office and a executive board member with the Canadian Council on Social Development. pulkingh@sfu.ca 